DOI https://doi.org/10.18551/rjoas.2017-12.11

\title{
THE INFLUENCE OF SOCIAL CAPITAL AND ENTREPRENEURSHIP ORIENTATION ON BUSINESS STRATEGY AND PERFORMANCE OF MICRO, SMALL AND MEDIUM ENTERPRISES: A STUDY IN TIMOR TENGAH UTARA
}

\author{
Fina Yohanes*, Arifin Zainul, Mawardi M. Kholid \\ Faculty of Administrative Science, University of Brawijaya, Indonesia \\ *E-mail: johanesfina@yahoo.co.id
}

\begin{abstract}
This research aims to explain the Influence of Social Capital, Entrepreneurship Orientation on Business Strategy and Performance of Micro, Small and Medium Enterprises (MSME). The population of this study is owners and/or managers of MSME furniture processing industry and traditional weaving industry in district of Timor Tengah Utara with a sample of 40 respondents. Sampling technique is done using simple random sampling. The analysis data technique used in this research is Partial Least Square approach. The results of this study indicate that social capital and entrepreneurship orientation have a significant effect on the business strategy and performance of MSME.
\end{abstract}

\section{KEY WORDS}

Social capital, entrepreneurship orientation, business strategy, performance.

Micro, Small, and Medium Enterprise (MSME) is one of the leading driving forces in the economic development of the society. MSME sector reaches up to the lowest layer of the community. Therefore, it plays a vital role to create the economic growth and employment. Various countries have acknowledged the contribution of MSME, but its implementation is different from one country to another. Its role in encouraging the rate of economic growth and employment is enormous. In some countries, MSME is able to encourage the real sector in various business fields to contribute to the formation of GDP (Gross Domestic Product) in many cases. The contribution to the GDP is higher compared to other Countries in Asia amounted to $57.8 \%$. Although Indonesian MSME tends to serve the local market which is proven by the low export value amounted to $15.8 \%$ below Philippines, Thailand, and Malaysia. This is quite reasonable due to extensive domestic market and most of these business actors have limited understanding of the export activity.

Maintaining and developing the national economy can be done by involving as many economic actors as possible. Based on their potential on the basis of the justness for all of the stakeholders. However, life capacity of the MSME as a business unit is determined by many factors. The results of a survey conducted by WEF (2014-2015), the biggest obstacle in Indonesia is corruption followed by access to financing and inflation. The performance of MSME should be carried out simultaneously and comprehensively to overcome these obstacles and to develop MSME, which can be done through the continuous effort from various agencies and ministries, as well as the banking sector, where coordination is done by the ministry of MSME.

So far, various approaches, perspectives and business strategies have been done to improve the performance of MSME and to know the performance development of MSME. Approach and perspective to be done to describe the phenomenon of MSME to maintain and improve the business performance such as perspective of social capital. Social capital refers to the part of a social organization such as trust, norm, and network that can improve the efficiency of the community by facilitating the coordinated actions (Putnam, 1995a: 167, in Field, 2003). Newton (1997: 575, in Leksono, 2009) argues that there are three elements in the social capital namely: a) norm and value b) working network or organization/institution and c) its consequences and result. Recently, it is acknowledged that traditional capital type (natural, human and physical resources) only determines partially from the whole process of economic growth. Another determining factor that has been relatively neglected is the way 
economic actors interact and organize themselves to encourage the development and growth. This neglect is described as the loss of one of the link series of economic growth and development namely social capital (Grootaert, 1998, in Vipriyanti, 2014).

Components of social capital should be maximally utilized by business actors in improving the performance of MSME where social networks are used by business actors to gain market access, knowledge, cooperation, tool aid, capital and others. While the belief and norm are used by business actors to build commitment with other parties in order to maintain the existing cooperation.

The orientation of entrepreneurship has an effect on business performance (MSME). Entrepreneurship is a knowledge that studies about the values, ability, and behavior of an individual in facing the life's challenges. Entrepreneurship is a knowledge that has the object with the ability to create something new and different (Zimmerer and Scarborough, 1998, in Kristanto, 2009). Entrepreneurship and innovation are central to the creative process of the economy. Innovation is a specific function of entrepreneurship as a way of creating resources by utilizing the existing resources to produce wealth Drucker (1998, in Kristanto, 2009). Entrepreneurship process is typically the same as the process of management strategy. In the entrepreneurship research field, the orientation of entrepreneurship has become an important construct. The underlying proposition for the importance of entrepreneur orientation is that the existence of research that proves the existence of entrepreneurship orientation (proactive, innovative and risk-taking). It has a positive influence on the performance of MSME (Zhi and Jintong. 2012). The orientation of entrepreneurship is a core element of the form of business organization, especially in the improvement of the business performance. The need for achievement is the basis of the innovation as a strong psychological factor that triggers someone to do an activity. As long as the goals have not been clearly achieved to be the key factor in determining the action to improve the business performance.

In addition, the strategy is important activities required to achieve the goal. Porter (1985) in Hamili, 2016) explains that the most important meaning of understanding the strategy as taking different action from a competitor in an industry to achieve a better position. According to David (2012, in Faruq and Usman, 2014), the strategy is a shred tool with a long-term goal to be achieved. Meanwhile, Hitt (2012, in Faruq and Usman, 2014) argues that strategy is an integrated and coordinated series of commitment and action designed to exploit the key competency and gain competitive advantage.

Therefore, business strategy is a regular and pragmatic approach that can be used by the organization. Both for public and private in the current decision making for the future of the organization.

This research is selected and can be done based on the preliminary supervision and observation. The business actors in Timor Tengah Utara (TTU) District is experiencing the symptom of fundamental problem commonly suffered that is the weakness in the field of entrepreneurship such as the lack of innovation, not ready to take the risk, less proactive and tend to wait for consumers to come. In addition, most of the business actors have not built the capital modal among business groups that often lead to unhealthy competition, and has a limitation in formulating the business strategy beneficial to the business life in the future.

Improvement of the performance of MSME in the TTU District should be done to survive and compete, thus the business actors should develop entrepreneurial oriented spirit which includes: innovative, risk-taking, and proactive. They can also build social capital among business groups that include trust, networking, and norms in running a business, as well as building business strategies that will direct and facilitate a person in achieving goals. Furthermore, the formulation of the problem in this research is:

- How does the social capital affect the business strategy?

- How does entrepreneurial orientation affect the business strategy?

- How does social capital affect the performance of MSME?

- How does entrepreneurship orientation affect MSME performance?

- How does business strategy affect MSME performance? 


\section{LITERATURE REVIEW}

Increasing competition among business actors as well as the government's effort to improve the economic life of the community attracts the economist to conduct a research on micro, small and medium-scale business related to social capital, entrepreneurship orientation, business strategy, and performance. Previous studies have become the basis for developing the conceptual framework of this study. Direction and purpose of the research can be seen based on the conceptual framework that has been built.

The social capital variable is developed based on the Putnam's (1996) theory that characteristics of social organization such as belief, norm, and network enabling the participants to act together more effectively to pursue common goals. In addition, it is also developed by Giusta (1999) and Casson \& Delia Giusta (2004) that capital modal can improve the economic performance. Social capital can be interpreted as the characteristic of social organization in the form of social network, norm, and belief that play a role in the mutual cooperation. Thus, the measurement of social capital in this research is done based on the indicator of the network, norm, and trust attitude.

Entrepreneurship orientation variable is developed based on the research conducted by Suci (2009). Her research found that the entrepreneurship orientation influences the business strategy. Meanwhile, Zhi and Jintong (2012) indicate that entrepreneur-oriented companies become the antecedents to the implementation of business strategy. When the management implements entrepreneurship through innovation, risk-taking and proactive in each of their business activity, they are more likely to adopt a strategy to cope with their growing business environment dynamic. Theoretically, this study is supported by the theory from McGrath (1996) who suggests that entrepreneurial orientation can be an important measurement method on how a company is organized. This is also an important entrepreneurial contribution to entrepreneurial performance.

Meanwhile, business strategy variable is developed based on the theory of Barney and Hesterly (2008, in Faruq and Usman, 2014). The strategy is described as a theory on how a company achieves competitive advantages. Long-term strategic planning is derived from the company's effort to seek the basis of the competitive advantage from generic strategies (Pearce II and Robinson, 2007) namely:

- Striving to achieve low cost (overall Cost leadership) in the industry.

- Striving to create unique products for various customers or differentiation.

- Striving to serve a specific demand on one or more groups of consumers or industry (Focusing) on cost or differentiation.

The performance variable of MSME is measured based on the research conducted by Samosir et al. (2016) and Soares (2014), namely Sales growth, manpower growth and human resources. Performance is about what to do and how to do it. Performance is the result of work that has a strong relationship with the goal of organizational strategy, consumer satisfaction and economic contribution (Amstrong and Baron, 1998, in Wibowo, 2007).

According to Putnam (1996, in Fitriawati, 2010), the features of social organization, such as trust, norm and network that enable participant to act together more effectively to pursue common goals.

Meanwhile Fitriawati in her research states that social capital plays a very important role in small industry strategy. Trust has an important role in the production process, norm or regulation plays an important in establishing price as well as work arrangement, and the network has an important role in the business fabric for marketing. Handayanti et al (2012) argue that social capital construct can statistically affect the competitiveness.

One of the resources that can provide competitive advantage is the resources developed through various social approaches with its social attribute (Oliver, 1997) known as social capital (Coleman, 1988). In this regard, social capital is seen as one of the instruments that encourage the growth and development of competitive advantage which is the target of business strategy mediating the process in achieving the goal. 
Three key elements in the social capital are network, trust and norm. Network is used to access resources needed to achieve common goals and benefits. Trust and norm are used to build commitment to maintain a cooperative relationship and encourage someone to work with others to create productive activity or action together.

H1: Social capital positively affects business strategy.

Roopke (2004) states that entrepreneurship is the process of creating something new (new creation) and making something different from the existing stuff (innovation), the purpose is to achieve individual well-being and added value of the society. Meanwhile, empirical study conducted by Suci (2009) found that entrepreneurial orientation influences business strategy.

An important element of entrepreneurship orientation is innovative, proactive and ready for the risk-taking, thus an entrepreneur or business actor is required to transform or apply the three key elements in conducting his or her business to survive and compete with an increasingly dynamic business environment.

H2: The Entrepreneurship Orientation positively affects the business strategy.

According to Putnam, the definition of 'social capital' is part of social life, network, norm, and trust that encourage the participants to act effectively to achieve common goals (Putnam, 1996, in Field, 2003).

Social capital was developed theoretically by Giusta (1999) and Casson \& Delia Giusta (2004) and empirically by Knack and Keefer (1997) who state that social capital can improve economic performance. While empirically, Astuti (2015) states that social capital affects the performance.

Social capital has important elements in the form of network, norm, and trust. Thus, social capital can affect the business performance at the innovation level, access to the market and its role in obtaining information, technology and giving other resources.

H3: Social Capital has significant effect to MSME Performance.

According to McGrath (1996), entrepreneurship orientation can be an important measurement on how a company is organized and an important entrepreneurship contribution to its performance. Meanwhile, Zhi and Jintong (2012) indicate that entrepreneur-oriented companies are becoming the antecedent to the implementation of the business strategy. When management is applying entrepreneurship by being innovative, courageous of risk-taking and proactive in each of their business activity. They tend to appropriately implement the strategy to cope with their increasingly dynamic business environment. Then, the entrepreneurship orientation reflects the tendency of the owner (entrepreneur) to be included in the innovative behavior, courageous of risk-taking, and proactive in defeating the competitor and a chance to improve their business performance.

H4: Entrepreneurship Orientation has a significant effect on MSME Performance.

According to Barney and Hesterly (2008, in, Faruq and Usman, 2014), the strategy is defined as a theory on how a company achieves competitive advantages. While long-term strategic planning is derived from the company's entrepreneur to seek the basis of the competitive advantage of generic strategies (Pearce II and Robinson, 2007): striving to achieve low cost (overall Cost leadership) in the industry; striving to create unique products for various customers or differentiation; striving to serve a specific demand on one or more groups of consumers or industry (Focusing) on cost or differentiation.

Business strategy is the activities undertaken to achieve the goals and gain advantage through low-cost strategy, differentiation strategy and focus strategy that will also contribute to the improvement of business performance. This statement refers to the research conducted by Dani et al (2013) and Maskur (2015) who state that business strategy has a significant effect on performance improvement.

H5: Business strategy has a significant effect on MSME Performance.

Therefore, this research will examine and explain the Influence of Social Capital and Entrepreneurship orientation on Business Strategy and Performance of Micro, Small and Medium-Scale Business. In accordance with the above description on the background of the problem, the foundation of the theory and previous research, Figure 1 shows the research model. 


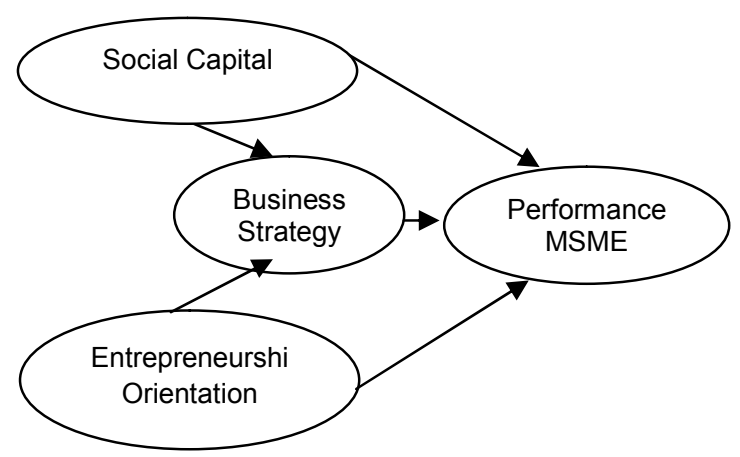

Figure 1 - Research Model

\section{METHODS OF RESEARCH}

The research method used in this study is explanatory research with quantitative approach. This research was conducted in Timor Tengah Utara (TTU) District. The number of population in this research amounted to 143 units of MSME and the sample amounted to 40 units actor of MSME furniture processing industry and lkat weaving processing industry. Social capital is measured using three items developed from research conducted by Fitriawati (2010) and Astuti (2015). Entrepreneurship orientation is measured using three items developed from research conducted by Suci (2015) and Zhi \& Jintong (2012). Business strategy is measured using three items developed from research conducted by Dani et al (2013) and Maskur (2015). And MSME performance is measured using three items developed from research conducted by Samosir et al (2018) and Wicaksono and Nuvriasari (2012).

\section{RESULTS OF STUDY}

H1: Social Capital has a significant effect on Business Strategy. Social Capital has a significant influence on Business Strategy with path coefficient amounted to 0.5093 and $t$ statistic amounted to 4.3942 bigger than t table (1.960) and significant or $p \leq 0.05$. This shows that if social capital is well managed then it can be an opportunity for MSME in developing and maintaining the business. Through the research result, the business can be improved by fixing the business strategy and affecting the future of furniture industry as well as Ikat weaving industry in Timor Tengah Utara-Kefamenanu District. By doing this, the business will improve faster and will be ready to compete with the increasingly dynamic business environment.

$\mathrm{H} 2$ : Entrepreneurship Orientation has a direct and significant positive influence on the Business Strategy. Entrepreneurship Orientation has a positive influence on the Business Strategy with the path coefficient of 0.4075 and $t$ statistics of 2.8354 greater than $t$ table (1.960) and significant or $p \leq 0.05$. Entrepreneurship Orientation undertaken by the owners of MSME in their business activity is capable of producing high competitiveness if they can act more creative by inventing something new, different and unique while generating important values for the customers. Proactively anticipate the competitors, as well as taking the risks in business, but still paying attention to innovative products. The entrepreneurship orientation will contribute positively to the creation of competitive advantages through increased business productivity.

H3: Social Capital has a direct and significant positive influence on the Performance of MSME. Social Capital has a positive influence of 2.2058 smaller than t table (1.960) and significant or $p \leq 0.05 \%$. This finding indicates that if social capital is built and manage well, it will be a chance for MSME to develop and improve the performance of MSME. This will give the positive effect from the generated results which is improving the MSME and affecting the future of increasingly popular furniture industry and lkat weaving industry in Timor Tengah Utara-Kefamenanu District. 
H4: Entrepreneurship Orientation has a direct and significant positive influence on the Performance of MSME. Entrepreneurship Orientation has the positive influence on the Performance of MSME with the path coefficient of 0.3504 and t statistics of 2.6955 smaller than $t$ table (1.960) and significant of $p \leq 0.05 \%$. This result indicates that entrepreneurship orientation gives significant influence on the Performance of MSME. Better entrepreneurship orientation will improve the Performance. Thus, one of the methods to keep and improve the performance of MSME to be maximal is through entrepreneurship orientation in the form of innovative, proactive and readiness in taking the risk.

$\mathrm{H} 5$ : Business Strategy has a direct and significant positive influence on the Performance of MSME. Business strategy has a positive influence on the performance of MSME with the path coefficient of 0.3483 and $t$ statistics of 2.6955 greater than table (1.960) and significant or $p \leq 0.05 \%$. These results are in accordance with the information obtained in the field. In achieving the performance requires the implementation of an appropriate business strategy. The reason is that appropriate business strategy will give guidance to the implementation of various activities which will give positive effect to the improvement of performance of the MSME.

\section{CONCLUSION}

The research results on MSME in the furniture processing industry and lkat weaving industry in Timor Tengah Utara (TTU) District have interesting results in observing the general condition of business in Indonesia. The economic situation that forces people to start their own business has created a thriving economic climate and micro, small and mediumscale business in Indonesia proves to be a strong economic support against various domestic and abroad economic fluctuations. One of the evidence is the economic crisis of 1998 in Indonesia when many big companies and banks went bankrupt, small businesses were still running and developing as a nation's hope in improving its economy at that time. Therefore, improvement is needed for a better entrepreneurship and easier access to the resources. Education and training that are provided by the government in developing the business actors will be useful to improve their business. This can be done by building the business network from various creative thinking processes to support the performance and competitiveness in Indonesia. The research is still very limited due to the business field of the respondents covering only furniture processing industry and lkat weaving industry. Therefore, the future research is expected to have more diverse respondent characteristics with a large number and types of micro, small and medium-scale business in Indonesia ranging from manufacturing industry, service, or other creative businesses.

\section{REFERENCES}

1. Dani Ibrahim, M.S Idrus, Umar Nirman, Achmad Sudiro. 2013. Business Strategy Role as Mediation Of Management Capability And Orientation Of Entrepreneurship On Business Performance. Journal of Management Research. Vol. 5 No. 1.

2. Faruq, M.A. 2014. Penyususnan Strategi Bisnis dan Strategi Operasi Usaha Kecil Dan Menengah Pada Perusahaan Konnveksi Scissors. Jurnal Manajenen Teori Dan Terapan. Tahbu. 7, No. 3.

3. Field, J. Modal Sosial. Penerjemah Nurhadi. Yogyakarta. Kreasi Wacana.

4. Fitriarwati. 2010. Modal Sosial Dalam Strategi Industri Kecil. Vol4. No 1

5. Hamili, A.Y. 2016. Pemehaman Strategi Bisnis dan Kewirausahaan. Jakarta: Prenadamedia Group.

6. Maskur. 2015. Pengeruh Orientasi Kewirausahaan. Kemampuan Manajemen, Dinamika Lingkungan Terhadap Kinerja Bisnis Dan Kinerja Industri Kecil Menegah. Disertasi. Program Doktor. Universitas Brawijaya. Malang.

7. Pearce II J.A. and Robinson Jr. R.B. 2007. Strategic Manajemen Formulation, Implementation and Control, 10th ed. McGraw Hill-Boston.

8. Porter, E.M. 2005. Competitive Strategy, Collier Macmillan. Release:1998 
9. Roopke, J. 2004. On Creating Entrepreneurial Energy in The Ekonomi Rakyat The Ekonomi Rakyat The Café of Indonesian Cooperative. ISEI, Bandung. Jurnal Ekonomi Kewirausahaan, 3(2): 43-61.

10. Samosir, Magdalena Silawati, Made Suyana Utama, A.A.I.N. Marhaeni. 2016. Analisis Pemberdayaan dan Kinerja UMKM Terhadap Kesejahteraan Pelaku UMKM. E-Jurnal Ekonomi dan Bisnis Universitas Udayana 5.5 (2016):1359-1384. ISSN:2337-3067

11. Siwi Rami Astuti. 2012. Pengaruh Modal Sosial Relasional, Modal Sosial Dimensi Struktural, Dan Motivasi Terhadap Kinerja In-Role Dan Ex-Role Karyawan "Koperasi Karyawan Angkasa Pura I (Kokapura Avia) Ground Handling. Jurnal Manajemen Vol. 2 No. 2. ISSN 2088-7698.

12. Suci, R.P. 2009. Pengaruh Orientasi Kewirausahaan, Dinamika Lingkungan, Kemampuan Manajemen, Serta Strategi Bisnis Terhadap Kinerja. Malang. Dian Prima Lestari.

13. Vipriyanti, N.U. 2014. Modal Sosial Dan Pembangunan Wilayah. Malang: Tim UB Press.

14. Wicaksono, G. and Nuvriasari, A. 2012. Meningkatkan Kinerja UMKM Industri Kreatif Melaluii Pengembangan Kewirausahaan dan Oriantasi Pasar: Kajian pada Peran Serta Wirausaha Wanita. Jurnal Sosio Humaniora Vol. 3, No. 4. ISSN:2078-1899.

15. Zhi, T. and Jintong, T. 2012. Entrepreunarial Orientation and SME performance in China's Changing inviorement: The moderating effects of strategies. Springer Science Business Media. 